\title{
FAKTOR YANG MEMPENGARUHI VOLUME PRODUKSI PADA PT. YONGJIN JAVASUKA GARMENT FACT 1
}

\section{FACTORS THAT INFLUENCE PRODUCTION VOLUME IN PT. YONGJIN JAVASUKA GARMENT FACT 1}

\author{
I.C. Kusuma, G. Pebrianti \\ Program Studi Akuntansi Fakultas I.C. Kusuma Ekonomi Universitas Djuanda Bogor \\ Email : indra.cahya.k@unida.ac.id, ginafebriantii@gmail.com
}

\begin{abstract}
Production is an activity to create or add value to an item to meet needs. The activity of increasing the usefulness of an object without changing its form is called service production. Whereas the activity of increasing the usefulness of an object by changing its nature and shape is called the production of goods. This study aims to determine the effect of raw material inventory and machine hours on production volumes. The population used in this research is data on raw material inventory, machine hours and production volume of PT. Yongjin Javasuka Garment Fact 1 from 2015-2018. The sample of this research is all data related to the supply of raw materials, machine hours and production volume in 2015-2018 using the time series method for 48 months. Analysis of the data used in this study is using multiple regression. From the results of research using multiple linear regression and simultaneous tests with the $F$ test it can be seen that the supply of raw materials (X1) and machine hours (X2) simultaneously influence the production volume $(Y)$. While based on the $t$ test it can be seen that the supply of raw materials (X1) partially significantly influences the production volume (Y) and machine hours (X2) partially significantly influences the production volume $(Y)$.
\end{abstract}

Keywords: Machine Hours, Production Volume, Raw Material Inventory

\begin{abstract}
ABSTRAK
Produksi adalah suatu kegiatan untuk menciptakan atau menambah nilai guna suatu barang untuk memenuhi kebutuhan. Kegiatan menambah daya guna suatu benda tanpa mengubah bentuknya dinamakan produksi jasa. Sedangkan kegiatan menambah daya guna suatu benda dengan mengubah sifat dan bentuknya dinamakan produksi barang. Penelitian ini bertujuan untuk mengetahui pengaruh persediaan bahan baku dan jam mesin terhadap volume produksi. Populasi yang digunakan dalam penelitin ini adalah data mengenai persediaan bahan baku, jam mesin dan volume produksi PT. Yongjin Javasuka Garment Fact 1 dari tahun 2015-2018. Sampel penelitian ini yaitu seluruh data yang bersangkutan dengan persediaan bahan baku, jam mesin dan volume produksi dai tahun 2015-2018 dengan menggunakan metode time series sebanyak 48 bulan. Analisa data yang digunakan dalam penelitian ini yaitu menggunakan regresi berganda. Dari hasil penelitian dengan menggunakan regresi linier berganda dan uji simultan dengan uji $\mathrm{F}$ dapat diketahui bahwa persediaan bahan baku (X1) dan jam mesin (X2) berpengaruh secara simultan terhadap volume produksi (Y). Sedangkan berdasarkan dengan uji $\mathrm{t}$ dapat diketahui bahwa persediaan bahan baku (X1) secara parsial berpengaruh signifikan terhadap volume produksi $(\mathrm{Y})$ dan jam mesin (X2) secara parsial berpengaruh signifikan terhadap volume produksi (Y).
\end{abstract}

\section{Kata Kunci: Jam Mesin, Persediaan Bahan Baku, Volume Produksi}




\section{PENDAHULUAN}

Memasuki dunia bisnis di dunia ekonomi termasuk dalam bidang manufaktur yang semakin luas saat ini, dan perusahaanperusahaan yang telah berdiri sedang berlomba-lomba untuk mendapatkan hasil pencapaian yang bagus, setiap perusahaan memerlukan cara untuk menjadikan perusahaannya tumbuh dan berkembang, cara untuk mengembangkan perusahaan yaitu dengan cara mengatur ketersediaan bahan baku untuk mendukung produksinya. Agar sukses dalam menciptakan suatu produk maka setiap perusahaan harus dapat menetapkan strategi manajemen operasional yang di dalamnya merupakan kegiatan mengatur dan mengkoordinasikan alat dan sumber daya manusia, sumber daya alat, sumber daya biaya dan bahan secara efisien dan efektif yang berguna untuk menghasilkan dan menambah nilai kegunaan barang dan jasa.

Tujuan umum dari setiap perusahaan yaitu untuk memperoleh laba, dan hal ini akan tercapai apabila ketersediaan bahan baku yang memadai dan pengiriman bahan baku yang tepat waktu, ketersediaan bahan baku ini adalah hal yang paling utama dalam setiap produksi. Faktor yang dapat mempengaruhi lancarnya ketersediaan bahan baku yaitu dari pemasok atau supplier, pelanggan dan para pelanggan dan para pesaing yang bekerja di dalam aspek produksi yang sama.

Badriah (2018) "Persediaan adalah elemen penting dari modal kerja dan aktiva yang setiap saat mengalami perubahan, dapat disimpulkan bahwa persediaan adalah aktiva yang harus tersedia di perusahaan pada saat dibutuhkan demi kelancaran dalam menjalankan perusahaan". Persediaan bahan baku adalah asset perusahaan yang sangat vital, setiap perusahaan proses produksinya memerlukan persediaan bahan baku, pengelolaan persediaan yang tepat dan ekonomis sangatlah penting, dengan adanya persediaan yang tersedia cukup digudang bisa memperlancar proses produksi, pelayanan yang sesuai kepada konsumen atau buyer, dapat menghindari kekurangannya bahan baku, jadwal pengiriman atau ekspor bisa sesuai dengan yang telah direncanakan dan dapat menghindari kegagalan produk yang dapat menyebabkan kerugian perusahaan.

Bahan baku merupakan hal yang utama dalam setiap produksi. Bahan baku merupakan kebutuhan pokok dalam memproduksi barang, untuk memperlancar suatu produksi maka pasokan bahan baku harus lancar dan tidak ada kemacetan karena ketika stok bahan baku kurang atau ada kemacetan maka produksi tersendat. Tetapi dalam inventory stock tidak baik apabila penyediaan bahan baku itu secara berlebihan karena akan menimbulkan tertanamnya modal secara tidak produktif dan perusahaan mengalami kerugian. Persediaan yang di peroleh melalui impor dan dari beberapa supplier lokal, bahan baku yang diimpor di lakukan oleh head office atau perusahaan utama yang benama Hojeon Limited Korea sedangkan bahan baku dari supplier lokal yaitu bahan baku seperti benang, zipper dsb. Inventory Control di perusahaan pada umumnya menggunakan persediaan pengaman yaitu persediaan tambahan untuk menghindari kekurangan persediaan (stock out).

Suatu produk didasarkan atas karakteristik dan keinginan dari produk yang diproduksi, akibatnya akan membuat kesulitan bagi perusahaan, faktor-faktor yang menyebabkan suatu produk tidak sesuai harapan, disebabkan oleh bahan baku, tenaga kerja, kinerja mesin.

Kegiatan produksi tidak lepas dari tenaga kerja karena yang sangat dominan demi kelancaran suatu produksi sampai mendapatkan hasil dari suatu kegiatan produksi adalah tenaga kerja. Dengan tenaga kerja suatu produksi itu akan cepat terselesaikan dengan baik. Apabila tenaga kerja itu dididik dengan baik hingga menjadi tenaga kerja yang professional yaitu tenaga kerja yang memiliki keterampilan dan kemampuan sehingga mampu bekerja lebih 
produktif pasti hasil produksi yang diperoleh akan sesuai dengan target yang telah ditentukan. Oleh karena itu untuk menunjang hasil yang cukup dan bisa mengejar pengiriman barang atau penjualan membutuhkan waktu untuk memproduksi sebuah barang, satuan waktu yang dibutuhkan setiap orang atau setiap mesin untuk mencapai hasil tertentu. Faujiah (2017) Kapasitas produksi disimpulkan sebagai jumlah maximum output yang dapat diproduksi dalam satuan waktu tertentu. Besarnya kapasitas suatu produksi tidak terlepas dari besarnya kapasitas mesin yang dibutuhkan untuk suatu produksinya. Mesin yang digunakan di PT.Yongjin Javasuka Garment untuk memproduksi produknya yaitu mesin jahit yang dioperasikan oleh sumber daya manusia atau karyawan produksi. Minimal jam kerja karyawan perhari yaitu 8 jam perhari maka untuk 20 line produksi perusahaan membutuhkan waktu 160 jam perhari. Proses produksi yang dijalankan menggunakan mesin yang dijalankan oleh sumber daya manusia membutuhkan proses waktu yang cukup lama untuk setiap produksinya dan bisa dikatakan belum efisien untuk mendapatkan hasil seperti yang diinginkan karena tenaga kerja yang terbatas dan penggunaan kapasitas mesin sudah ditentukan, karena kecepatan sebuah mesin di kendalikan oleh setiap tenaga kerja

Tabel 1. Persediaan bahan baku, Jam Mesin, dan Volume Produksi
PT.Yongjin Javasuka Garment merupakan salah satu perusahaan yang bergerak di bidang manufaktur yang berlokasikan di Jl. Raya Siliwangi KM. 35,

Kp. Pajagan Desa Benda, Kecamatan Cicurug Kabupaten Sukabumi, dan perusahaan ini akan menjadi objek penelitian penulis, PT. Yongjin ini memproduksi jaket dan celana dari buyer ternama. Di PT.Yongjin Javasuka Garment ini $70 \%$ memproduksi jacket dari berbagai brand ternama, dan 30\% memproduksi celana. Pada produksi jacket persediaan bahan baku ada berbagai macam komponen mulai dari bahan mentah seperti kain yang belum dipotong atau belum siap pakai, dan aksesories seperti zipper, puller dll. Persediaan bahan baku terfokus pada produksi jaket, data yang dipakai untuk persediaan bahan baku adalah data fabric (kain atau bahan) dan untuk setiap produksi sebuah jaket dibutuhkan 2 meter bahan. Proses produksi di perusahaan ini terkadang terhambat karena persediaan yang telat datang, dan Jam mesin yang kurang untuk suatu proses produksi dan akan berakibatkan pada volume produksi atau hasil produksi yang kurang memuaskan sehingga pengiriman (ekspor) tidak sesuai dengan jadwal. Adapun data persediaan bahan baku, Jam mesin dan volume produksi pada tahun 2016 ini pada Tabel 1. 
Berdasarkan tabel 1. diatas volume produksi terjadi kenaikan dan penurunan, terjadinya kenaikan dan penurunan suatu volume produksi itu sendiri tergantung pada pemesanan oleh pihak buyer, untuk persediaan bahan baku itu sendiri lebih besar dibandingkan dengan volume produksi karena pada saat pemesanan managemen perusahaan menggunakan

safety stock yaitu persediaan pengamanan, perusahaan melakukan ini karena menghindari terjadinya kekurangan pada saat proses menjahit, untuk mengantisipasi apabila ada barang yang rusak. Dan pada jam mesin terjadi suatu kenaikan atau penurunan, karena hal tersebut tergantung pada kerumitan sebuah jaket dan waktu pengiriman, tingkat kerumitan jaket berpengaruh pada hasil produksi yang lebih sedikit yang mengakibatkan jam kerja karyawan ditambah (lembur) guna untuk mencapai tanggal pengiriman agar tidak delay pada saat pengiriman (ekspor). Dalam setiap produksi perusahaan pasti mengalami "Idle Capacity". Idle capacity adalah suatu kapasitas mesin yang tidak terpakai atau kapasitas mesin yang menganggur (available), idle capacity biasanya disebabkan oleh adanya permintaan yang rendah atau permintaan yang tidak cukup tinggi, dalam proses produksi di PT. Yongjin Javasuka Garment Fact 1 management perusahaan mengantisipasi untuk mencegah adanya idle capacity yang berlebih maka pada saat produksi kapasitas mesin yang sedang tidak beroperasi di line maka operator produksi di line tersebut dibantukan untuk memproduksi line lainnya sehingga di area produksi tidak ada mesin yang menganggur. Dilihat dari permasalahan yang telah dijabarkan dapat diketahui bahwa persediaan bahan baku yang menjadi faktor utama di bidang produksi manufaktur dan pada jam kapasitas mesin yang dibutuhkan produksi untuk memenuhi produksinya sesuai dengan pesanan buyer, maka penulis tertarik untuk meneliti sesuai dengan permasalahan tersebut dan mengambil judul "Pengaruh Persediaan Bahan Baku dan Jam Mesin

\section{Terhadap Volume Produksi pada PT. Yongjin Javasuka Garment 1"}

\section{METODE PENELITIAN}

Penyusunan penulisan penelitian ini, penulis menggunakan jenis penelitian kuantitatif dengan pendekatan deskriptif. Metode kuantitatif adalah metode yang digunakan untuk meneliti populasi atau sampel dengan pengumpulan data yang menggunakan instrument, serta analisis data bersifat kuantitatif/statistik, dengan tujuan untuk menggambarkan dan menguji hipotesis yang telah diterapkan.

\section{Populasi dan Sampel}

Hermawan (2018) Populasi adalah keseluruhan dari objek penelitian.. Populasi yang diteliti adalah data yang ada di PT. Yongjin Javasuka Garment mengenai persediaan bahan baku, Jam mesin dan volume produksi tahun 2015-2018.

Sampel merupakan bagian dari jumlah dari populasi, sampel yang diambil dari populasi hars mewakili. Sampel yang diambil dari penelitian ini yaitu berupa jumlah data yang berhubungan dengan persediaan bahan baku, Jam mesin dan volume produksi diambil dari suatu populasi yang akan diteliti secara rinci. Sampel yang diteliti yaitu seluruh jumlah dari populasi mengenai persediaan bahan baku, jam mesin dari tahun 2015-2018. Dalam penelitian ini, pengambilan sampel menggunakan pendekatan data berkala (time series) dengan skala bulanan. yaitu 48 bulan.

\section{HASIL DAN PEMBAHASAN Deskripsi Data}

Objek penelitian ini merupakan data sekunder yang telah ditentukan oleh peneliti dengan menggunakan metode time series, yaitu data dengan berdasarkan deretan waktu yang telah ditentukan yaitu data persediaan bahan baku, jam mesin dan volume produksi mulai dari tahun 20152018 yaitu sebanyak 48 bulan. persediaan bahan baku di perusahaan ini yaitu berupa Kain (fabric) atau bahan menah yang belum diproses dengan kedatangan kain dalam bentuk yard kemudian dipotong untuk setiap 
kebutuhan produksinya dan dirubah dalam bentuk meter, kain yang digunakan untuk setiap produksi jaket yaitu 2 meter untuk satu jaketnya.Jam mesin pada PT. Yongjin Javasuka Garment Fact 1 sama dengan jam bekerja karyawan, minimal jam kerja karyawan di perusahaan ini yaitu 8 jam/hari dan maksimal jam kerja di perusahaan ini yaitu $12 \mathrm{jam} / \mathrm{hari}$, penggunaan mesin disesuai dengan kebutuhan perusahaan untuk setiap model jaket yang sedang berjalan di produksi dan sesuai kebutuhan

\section{Regresi Linier Berganda}

Sugiyono (2017:206) menyatakan bahwa teknik regresi linier berganda (Multiple untuk mengejar waktu penjualan suatu produk. Perusahaan ini menggunakan mesin yang masih terbilang mesin baru karena mesin yang digunakan di produksi rata-rata mempunyai umur 3 tahun kebelakang. Dan Volume Produksi pada PT. Yongjin Javasuka Garment Fact 1 sesuai dengan pesanan dari buyer, yang sebelumnya telah di putuskan dengan pihak manajemen perusahaan yang kemudian dibuatkan schedule untuk produksi dengan tanggal pengiriman.

Regression Analis) digunakan Untuk memprediksi bagaimana pergantiannilai variabel dependen, bila nilai variabel independen dinaikan atau diturunkan nilainya.

\begin{tabular}{|c|c|c|c|c|c|c|}
\hline \multicolumn{7}{|c|}{ Coefficients $^{a}$} \\
\hline & & \multicolumn{2}{|c|}{ Unstandardized Coefficients } & \multirow{2}{*}{$\begin{array}{c}\text { Standardized } \\
\text { Coefficients } \\
\text { Beta } \\
\end{array}$} & \multirow[b]{2}{*}{$\mathrm{T}$} & \multirow[b]{2}{*}{ Sig. } \\
\hline \multicolumn{2}{|c|}{ Model } & B & Std. Error & & & \\
\hline \multirow[t]{3}{*}{1} & (Constant) & 1,030 & 1,066 & & ,966 & ,339 \\
\hline & PersediaanBahanBaku & 155 & ,047 & ,282 & 3,314 & ,002 \\
\hline & JamMesin & 1,038 & 116 & ,763 & 8,984 &, 000 \\
\hline
\end{tabular}

a. Dependent Variable: VolumeProduksi

Sumber : Data Diolah SPSS 24

$$
Y=a+\beta_{1} X_{1}+\beta_{2} X_{2}+e
$$

Berdasarkan Hasil output SPSS 24 dapat diketahui bahwa nilai dari persamaan regresi yaitu sebagai berikut :

$$
\mathrm{Y}=1.030+0.155 \mathrm{X}_{1}+1.038 \mathrm{X}_{2}+\varepsilon
$$

Interprestasi dari persamaan regresi dibawah ini yaitu :

1. 1.030 adalah angka konstanta (a) dari unstandardized coeffiecients. Dalam penelitian ini nilainya sebesar 1.030 . Angka ini merupakan angka konstanta yang memiliki arti bahwa jika tidak ada jam mesin $\left(\mathrm{X}_{1}\right)$ dan persediaan bahan baku $\left(\mathrm{X}_{2}\right)$ maka nilai Volum produksi $(\mathrm{Y})$ adalah 1.030 .

2. Hasil persamaan regresi untuk variabel jam mesin sebesar 1.038. hal tersebut menunjukan bahwa setiap peningkatan jam mesin sebesar satu satuan, dengan

\section{Pengujian Hipotesis}

Uji Simultan (Uji F) asumsi menyebabkan meningkatnya volume produksi sebesar 1.038 satuan.

3. Hasil persamaan regresi untuk variabel persediaan bahan baku sebesar 0.155 . hal tersebut menunjukan bahwa setiap peningkatan persediaan bahan baku sebesar satu satuan, dengan asumsi menyebabkan meningkatnya volume produksi sebesar 0.155 satuan.

Berdasarkan persamaan tersebut dapat ditarik kesimpulan persediaan bahan baku (X1) dan jam mesin (X2) berpengaruh positif terhadap volume produksi (Y) Oleh karena itu berarti hipotesis di terima karena variabel-variabel yang diujikan mempunyai nilai positif.

Uji statistik $F$ digunakan untuk memahami apakah variabel independen 
memiliki pengaruh secara bersama-sama terhadap variabel dependen atau terikat. Cara yang dipakai yaitu dengan memeriksa besarnya nilai probabilitas signifikannya.

Sumber : Data Diolah SPSS 24

Jika nilai probabilitas signifikansinya kurang dari 5\% maka variabel independen Sumber : Sumber : Data Diolah SPSS 24

Akan berpengaruh signifikan secara bersama-sama terhadap variabel dependen (Jannah,2018) .

Langkah-langkah pengujian hipotesis simultan dengan menggunakan uji $\mathrm{F}$ adalah sebagai berikut :

1. Menentukan siginifikasi sebesar $\alpha=5 \%$ Ho : $\beta_{1}, \beta_{2}=0$; Persediaan bahan baku, Jam mesin tidak berpengaruh secara Simultan terhadap volume produksi.

$\mathrm{H \alpha}: \beta_{1}, \beta_{2}=0$; Persediaan bahan baku, Jam mesin berpengaruh secara simultan terhadap volume produksi.

2. Kriteria pengambilan keputusan :

a. Jika F-hitung < F-tabel, variabel bebas secara bersama-sama tidak berpengaruh terhadap variabel dependen, Ho diterima dan $\mathrm{H}_{\alpha}$ ditolak.

b. Jika F-hitung > F-tabel, variabel bebas (independen) secara bersamasama berpengaruh terhadap variabel dependen, Ho ditolak dan $\mathrm{H}_{\alpha}$ diterima.

Sumber : Data Diolah SPSS 24

Berdasarkan hasil output SPSS 24 tersebut dapat diketahui bahwa hasil pengujian menggunakan uji $\mathrm{F}$, nilai signifikan $\mathrm{F}$ sebesar $0,00<0,05$ diperoleh nilai $F_{\text {hitung }}$ sebesar 46,827 , sedangkan $F_{\text {tabel }}$ sebesar 3,20 (46,827 > 3,20).

$\mathrm{F}_{\text {tabel }}=(\mathrm{k}: \mathrm{n}-\mathrm{k})$

$\mathrm{F}_{\text {tabel }}=(2: 48-2)$

$\mathrm{F}_{\text {tabel }}=2: 46$

$\mathrm{F}_{\text {tabel }}=3,20$

Hal ini membuktikan bahwa Ho ditolak dan $\mathrm{Ha}$ diterima. Kondisi ini bermakna bahwa Persediaan bahan baku dan jam mesin berpengaruh secara simultan dan signifikan terhadap volume produksi.

\section{Uji Parsial (Uji T)}

Uji beda t-test digunakan untuk menguji hipotesis secara parsial guna menunjukan pengaruh tiap variabel independen terhadap variabel dependen. Intrepetasi yang dijabarkan sebanding atas aturan pengambilan keputusan dalam uji $\mathrm{T}$ adalah sebagai berikut:

\section{ANOVA $^{\mathrm{a}}$}

\begin{tabular}{llr|r|r|r|r}
\hline Model & Sum of Squares & Df & Mean Square & F & Sig. \\
\hline 1 & Regression & 8,036 & 2 & 4,018 & 46,827 &, $000^{\mathrm{b}}$ \\
\cline { 2 - 7 } & Residual & 3,861 & 45 &, 086 & & \\
\cline { 2 - 7 } & Total & 11,897 & 47 & & & \\
\hline
\end{tabular}

a. Dependent Variable: VolumeProduksi

b. Predictors: (Constant), JamMesin, Persediaan BahanB aku

Sumber : Data Diolah SPSS 24

Dalam penelitian ini uji t diolah

menggunakan SPSS 24 dengan hasil seperti

dibawah ini:

$$
\begin{aligned}
& \mathrm{t}_{\text {tabel }}=(\alpha / 2 ; \mathrm{n}-\mathrm{k}-1 \text { atau df residual }) \\
& \mathrm{t}_{\text {tabel }}=(0.05 / 2 ; 48-3-1) \\
& \mathrm{t}_{\text {tabel }}=2,015
\end{aligned}
$$


Interpretasikan dari output SPSS dibawah sebagai berikut:

1. Variabel jam mesin dengan ini menunjukan seberapa besar variabel dari variabel terikat $\mathrm{Y}$ bisa didefinisikan oleh variabel X.

Model Summary ${ }^{b}$

\begin{tabular}{|c|c|c|c|c|}
\hline Model & $\mathrm{R}$ & R Square & Adjusted R Square & Std. Error of the Estimate \\
\hline 1 &, $822^{a}$ & 675 & ,661 & ,29292 \\
\hline
\end{tabular}

a. Predictors: (Constant), JamMesin, PersediaanBahanBaku

b. Dependent Variable: VolumeProduksi

$t_{\text {hitungsebesar } \quad 8,984>t_{\text {tabel }} \quad 2,015}$ dengan signifikasi $0,000<0,05$, maka Ho ditolak dan $\mathrm{Ha}$ diterima. Kondisi ini bermakna bahwa jam mesin secara parsial berpengaruh secara signifikan terhadap volume

2. persediaan bahan baku dengan thitungsebesar $3,314>t_{\text {tabel }} \quad 2,015$ dengan signifikasi $0,002<0,05$, maka Ho ditolak dan Ha diterima.

Kondisi ini bermakna bahwa persediaan bahan baku secara parsial berpengaruh secara signifikan terhadap volume produksi.

\section{Koefisien Determinasi}

Apabila nilai koefisien determinasi sama dengan 0 , maka variasi dari $\mathrm{Y}$ tidak dapat dijelaskan oleh $\mathrm{X}$ sama sekali. Sementara bila $R^{2}=1$, artinya variasi dari Y secara kesuluruhan dapat diterangkan oleh X. dengan kata lain bila $R^{2}=1$, maka semua titik pengamatan berada tepat pada garis regresi. dengan kata lain bila $R^{2}=1$, bahwa seluruh titik pemeriksaan berada tepat pada garis regresi. Dengan demikian baik buruknya suatu persamaan regresi ditentukan oleh $R^{2}$ yang memiliki nilai antara nol dan satu. Adapun rumus yang digunakan yaitu:

Coefficients $^{a}$

\begin{tabular}{|c|c|c|c|c|c|c|}
\hline \multirow{2}{*}{\multicolumn{2}{|c|}{ Model }} & \multicolumn{2}{|c|}{ Unstandardized Coefficients } & \multirow{2}{*}{$\begin{array}{c}\text { Standardized } \\
\text { Coefficients } \\
\text { Beta } \\
\end{array}$} & \multirow[b]{2}{*}{$\mathrm{t}$} & \multirow[b]{2}{*}{ Sig. } \\
\hline & & $\mathrm{B}$ & Std. Error & & & \\
\hline \multirow[t]{3}{*}{1} & (Constant) & 1,030 & 1,066 & & ,966 & ,339 \\
\hline & PersediaanBahanBaku & ,155 &, 047 & ,282 & 3,314 & ,002 \\
\hline & JamMesin & 1,038 &, 116 & ,763 & 8,984 &, 000 \\
\hline
\end{tabular}

a. Dependent Variable: VolumeProduksi

Analisis koefisien determintasi ( $R$ Square/ $R^{2}$ ) digunakan untuk mengetahui persentase sumbangan variabel pengaruh ekspektasi kinerja, ekspektasi usaha dan faktor sosial. Nilai koefisien determinasi Sumber : Data Diolah SPSS 24

Dari output model summary di atas diketahui nilai koefisien determinasi ( $\mathrm{R}$ square) sebesar 0,675. Besarnya angka koefisien determinasi ( $\mathrm{R}$ square) 0,675 sama dengan 67,5 persen. Sedangkan sisanya 32,5 persen dipengaruhi oleh variabel lain Selain dari regresi ini. Besarnya pengaruh dari variabel lain ini sering disebut error $(€)$.

$$
\mathrm{KD}=\mathrm{r}^{2} \times 100 \%
$$

Keterangan :

$$
\begin{aligned}
& \mathrm{KD}=\text { Koefisien Determinasi } \\
& r^{2}=\text { Koefisien Korelasi }
\end{aligned}
$$

Besarnya nilai koefisien determinasi ini umumnya berkisar antara 0-1, angka koefisien determinasi pada penelitian ini bernilai positif, maka dapat dikatakan bahwa terdapat pengaruh variabel persediaan bahan baku dan jam mesin terhadap volume produksi, dan nilai koefisien determinasi pada penelitian ini sebesar 0.675 mendekati 
angka 1, maka dapat dikatakan bahwa pengaruh variabel tersebut semakin kuat.

\section{Pengaruh Persediaan Bahan Baku terhadap Volume Produksi}

Berdasarkan hasil uji parsial menyatakan bahwa perseddiaan bahan baku berpengaruh terhadap volume

produksi, persediaan bahan baku adalah suatu aspek utama untuk terjadinya proses produksi, semakin baik sistem pengendalian internal mengenai persediaan bahan baku, maka akan semakin baik bagi kelancaran suatu produksi namun apabila semakin buruk sistem pengendalian internal persediaan bahan maka proses produksi akan terhambat. Pencatatan persediaan bahan baku di perusahaan ini menggunakan metode FIFO, dimana barang yang pertama datang adalah barang yang akan pertama diproduksi. Bahan baku yang digunakan di perusahaan yaitu bahan baku yang dikirim baik secara import maupun lokal, bahan baku merupakan bahan dasar utama yang digunakan untuk memproduksi garmen, ketika bahan baku minim tersedia, kemudian akan berakibat pada terhambatnya produksi garmen yang akan dihasilkan. Persediaan bahan baku di perusahaan ini yaitu berupa kain (fabric) atau bahan mentah yang belum diproses dengan kedatangan kain dalam bentuk yard maupun dalam bentuk roll, kemudian dipotong dengan menggunakan pola dan dirubah dalam bentuk meter sesuai dengan kebutuhan pada produksinya, kain yang digunakan untuk setiap produksi jaket yaitu 2 meter untuk satu jaketnya. Pengaruh yang ditunjukan pada uji hipotesis penelitian ini juga menyatakan hasil signifikasi adalah signifikan apabila melihat angka 0,002 < 0,05 . Hasil penelitian ini sejalan dengan Humaeni et al (2019) yang menyatakan bahwa Persediaan Bahan Baku secara parsial berpengaruh signifikan terhadap Volume Produksi, dikarenakan Banyaknya bahan baku mempengaruhi volume produksi. Apabila bahan baku cukup tersedia maka produk yang dihasilkan juga cukup. Namun jika sarana pengelolahan tidak baik, maka jumlah volume produksi akan menurun.

\section{Pengaruh Jam Mesin terhadap Volume Produksi}

Berdasarkan hasil uji parsial menyatakan bahwa Jam mesin berpengaruh terhadap volume produksi, jam mesin merupakan faktor pendukung perusahaan untuk mencapai waktu pengiriman yang telah ditentukan, apabila persediaan bahan baku melimpah sedangkan jam mesin yang kurang maka volume produksi tidak akan tercapai dengan maksimal. Penggunaan jam mesin di perusahaan ini disesuaikan dengan kebutuhan setiap produksinya yang terlebih dahulu sudah di buatkan schedule (perencanaan produksi) yang ditentukan berdasarkan pesanan setiap buyer (konsumen).

Hasil uji hipotesis memberikan hasil bahwa secara parsial jam mesin berpengaruh terhadap volume produksi. Hasil uji bisa dilihat pada nilai Variabel jam mesin dengan $t_{\text {hitungsebesar }} 8,894>t_{\text {tabel }} 2,015$ dengan signifikasi $0,000<0,05$. Hal ini disebabkan karena jam mesin di perusahaan ini disesuaikan dengan kebutuhan produksinya, dan mesin yang digunakan di perusahaan ini masuk ke dalam kategori baik, mesin-mesin yang digunakan berumur sekitar kurang lebih 3 tahun kebelakang. Hasil penelitian ini sesuai dengan teori yang dikemukakan oleh Hidayanti et al (2018) menurut handoko kapasitas mesin berpengaruh terhadap volume produksi, akan tetapi hasil penelitian ini tidak sama dengan peneliti terdahulu yang dilakukan oleh Hermawan (2018) yang menyimpulkan bahwa jam mesin tidak berpengaruh terhadap volume produksi karena adanya periode mesin using dan mesin-mesin yang sudah tua dan kinerja dari mesin pabrik itu juga rendah dan kurang produktif.

\section{Persediaan Bahan Baku, Jam Mesin terhadap Volume Produksi}

Hasil uji statistik menunjukan variabel persediaan bahan baku, jam mesin berpengaruh terhadap volume produksi. Hal ini bisa dilihat dari hasil pengolahan SPSS Uji $F$ yang menjelaskan bahwa nilai signifikan $F$ sebesar $0,00<0,05$ diperoleh nilai $F_{\text {hitung }}$ sebesar 46,827 , sedangkan $F_{\text {tabel }}$ 
sebesar 3,20 $(46,827>3,20)$ sesuai dengan pernyataan Ghozali (2012) yang menyebutkan kriteria pengambilan keputusan bahwa Jika F-hitung > F-tabel, variabel bebas (independen) secara bersamasama berpengaruh terhadap variabel dependen, Ho ditolak dan $\mathrm{H}_{\alpha}$ diterima, yang artinya bahwa persediaan bahan baku dan jam mesin bersama-sama berpengaruh terhadap volume produksi. Dari hasil uji koefisien determinasi menjelaskan bahwa tingkat pengaruh persediaan bahan baku dan jam mesin terhadap volume produksi yaitu $67,5 \%$ dan pengaruh dari variabel lain yaitu $32,5 \%$ yang artinya bahwa persediaan bahan baku dan jam mesin mempunyai hubungan yang kuat terhadap volume produksi baik secara simultan maupun secara parsial.

PT. Yongjin Javasuka Garment ini memiliki persediaan bahan baku yang cukup baik dan jam mesin yang memadai untuk setiap produksinya, tetapi pada prakteknya kendala yang dihadapi perusahaan ini yaitu sering terjadinya keterlambatan kedatangan persediaan bahan baku dari supplier (pemasok barang) yang disebabkan karena berbagai aspek, antara lain barang yang tidak siap kirim, kesalahan pada saat pengiriman atau kendala pada saat diperjalanan sehingga bisa menyebabkan produksi sedikit terhambat, namun semua masalah itu bisa teratasi dengan dijalankan produksi yang sudah siap terlebih dahulu sehingga produksi tetap berjalan dan jam mesin untuk pengerjaan produksi tersebut tetap pada waktunya. Jam mesin yang digunakan di perusahaan ini yaitu dengan waktu minimum 8 jam perhari dan waktu maksimum 12 jam perhari, penggunaan mesin disesuakan dengan jam kerja pada setiap produksi garmen tersebut. Penelitian ini sejalan dengan Dedi (2018) bahwa bahan baku berpengaruh secara signifikan dan bertanda positif terhadap produksi garmen. Tanda positif menunjukkan bahwa bilamana bahan baku tersedia sebesar 1 meter (m), maka produksi garmenpun meningkat sebesar 0,507 m.

\section{KESIMPULAN}

Kesimpulan dari penelitian ini yaitu dengan menguji hipotesis menggunakan uji $F$, persediaan bahan baku dan volume produksi berpengaruh secara simultan dan signifikan terhadap volume produksi.

Jumlah persediaan bahan baku secara parsial dan berpengaruh signifikan terhadap volume produksi, karena banyaknya persediaan bahan baku dapat mempengaruhi hasil produksi. Jika persediaan bahan baku cukup dan pengendalian atas persediaan baik maka produksi yang dihasilkan baik, tidak ada hambatan dan volume produksi sesuai yang inginkan. Namun jika persediaan bahan baku mengalami hambatan, tidak tersediaanya kain (fabric) yang cukup serta pengolahan atau pengendalian bahan baku tidak baik, maka volume produksi tidak sesuai ekspetasi dan estimasi pengiriman bisa terhambat.

Jam mesin berpengaruh secara signifikan terhadap volume produksi, karen apabila jam mesin yang dibutuhkan tidak memadai dengan apa yang diperlukan maka hanya akan bisa menghasilkan volume produksi tidak sesuai yang telah ditentukan, jam mesin merupakan faktor kedu selain persediaan bahan baku dalam menghasilkan volume produksinya, jam mesin dengan persedian bahan baku saling

berkaitan tanpa adanya jam mesin tetapi persediaan bahan baku yang melimpah maka volume produksi tidak sesuai harapan dan bisa mengakibatkan gagal ekspor. Dan apabila terjadi keterlambatan pada pengiriman maka perusahaan harus membayar pinalti atau denda, perusahaan akan merugi apabila terus-menerus terjadi keterlambatan pada setiap pengiriman.

Dari hasil penelitian Mesin yang digunakan di PT.Yongjin Javasuka Garment untuk memproduksi produknya yaitu mesin jahit yang dioperasikan oleh sumber daya manusia atau karyawan produksi. Minimal jam kerja karyawan perhari yaitu 8 jam perhari maka untuk 20 line perusahaan membutuhkan waktu 160 jam perhari untuk setiap produksinya. Maksimum jam mesin yang digunakan yaitu 12 jam perhari, di 
perusahaan ini penggunaan jam mesin tergantung pada produksi yang sedang berjalan dan tergantung pada tanggal pengiriman.

\section{SARAN}

Bagi Perusahaan sebaiknya lebih teliti lagi terhadap pemesanan, pengiriman dan penerimaan persediaan bahan baku, sehingga tidak adanya persediaan bahan baku yang telat datang atau persediaan bahan baku yang salah kirim, agar tidak menghambat jalannya produksi dan yang akan berakibatkan berkurangnya volume produksi dan lebih teliti lagi dalam hal quantity dan tanggal pengiriman agar bisa

\section{DAFTAR PUSTAKA}

Assauri, Sofjan. 2016. Manajemen Pemasaran. Rajawali Pers: Jakarta.

Carter, William K. 2015. Akuntansi Biaya buku 1, Edisi 14. Penerjemah: Krista, Salemba Empat : Jakarta

Badriah, E. (2018). Pengaruh biaya pemeliharaan dan perbaikan aktiva tetap terhadap volume produksi pada Perusahaan Daerah Air Minum Tirta Anom Kota Banjar. Jurnal Wawasan dan Riset Akuntansi, 3(2), 64-70

Dunia, Firdaus A, Abdulah, Wasilah. 2018. Akuntansi Biaya Edisi 3,Salemba Empat : Jakarta

Fakultas Ekonomi. 2016. Pedoman Penulisan Skripsi dan Karya Ilmiah, Universitas Djuanda: Bogor

Faujiah, I. (2017) Dampak Industri Garmen Terhadap Tingkat Kesejahteraan Masyarakat Desa Benda Kecamatan Cicurug Kabupaten Sukabumi (Bachelor's thesis, Jakarta: Fakultas Ilmu Tarbiyah Dan Keguruan UIN Syarif Hidayatullah). memprediksi jam mesin yang seharusnya digunakan dan bisa menghindari keterlambatan pada saat pengiriman produk Bagi peneliti selanjutnya yang bermaksud untuk melakukan penelitian yang serupa mengenai persediaan bahan baku, jam mesin terhadap volume produksi, disarankan untuk menambahkan variabel lain yang dapat berpengaruh secara langsung maupun tidak langsung seperti modal, biaya tenaga kerja serta biaya lain, ataupun bisa variabel $\mathrm{Y}$ dengan harga pokok atau harga jual suatu produk, sehingga akan memperluas penelitian.

Hermawan, D. J. (2018). Pengaruh jumlah persediaan bahan baku dan kapasitas mesin terhadap volume produksi pada UD. Cahaya Restu Kota Probolinggo. Jurnal Ekonomi Dan Manajemen Vol. 1 No, 2, 93-109.

Herjanto, Eddy. 2015. Manajemen Operasi dan produksi, Edisi Ketiga, Grafindo: Jakarta

Hidayanti, F., Yahdi, Y., \& Paramita, R. W. D. (2018). Pengaruh Volume Penjualan dan Biaya Operasional Terhadap Laba Bersih Perusahaan. In Proceedings Progress Conference (Vol. 1, No. 1, pp. 399-406).

Humaeni, A., Muanas, M., \& Sudradjat, S. (2019). Peranan Program Yongjin Erp Sebagai Sistem Informasi Akuntansi Pengendalian Persediaan Bahan Baku. Jurnal Ilmiah Akuntansi Kesatuan, 7(1), 213-218.

Jannah, M. (2018). Analisis Pengaruh Biaya Produksi Dan Tingkat Penjualan Terhadap Laba Kotor. Banque Syar'i: Jurnal Ilmiah Perbankan Syariah, 4(1), 87-112. 
Martana, D. P. A., Kirya, I. K., Yulianthini, N. N., \& SE, M. (2015). Pengaruh Jenis Produk, Biaya Promosi Dan Biaya Produksi Terhadap Volume Penjualan. Jurnal Jurusan Manajemen, 3(1).

Purwaningtyas, D., \& Sugiyanto, F. (2015). Analisis Pengaruh Tingkat Upah Dan Volume Produksi Terhadap Permintaan Tenaga Kerja Pada Industri Kecil Kerupuk Di Kabupaten Kendal (Doctoral dissertation, Fakultas Ekonomika dan Bisnis).

Setiawan, A. B., \& Andris, A. (2019). Analisis Faktor-Faktor Yang Mempengaruhi Pengalokasian Anggaran Belanja Modal Pada Kabupaten/Kota Di Provinsi Jawa Barat. JURNAL AKUNIDA, 5(1), 19.

Syam, A., \& Lasmana, A. (2016). Analisis Kinerja Keuangan PT. Sanshiro
Harapan Makmur dengan

Menggunakan Metode Du Pont

System. Jurnal Akunida, 2(1), 17-26.

Sugiyono. 2018. Metode Penelitian Kuantitatif, Alfabeta : Bandung

Warizal, W., Nirwanti, N., \& Setiawan, A. B. (2019). Return On Invesment (Roi), Economic Value Added (Eva), Dan Return Saham: Studi Empiris Pada Perusahaan LQ45. JURNAL AKUNIDA, 5(2), 47-58.

Warren, Carl S, dkk. 2016. Pengantar Akuntansi, Penerjemah : Novrys Suhardianto, Devi S.Kalanjati Salemba Empat : Jakarta

Wibowo, A., \& Kurniawati, E. P. (2015). Pengaruh Penggunaan Informasi Akuntansi terhadap Keberhasilan Usaha Kecil Menengah (Studi pada Sentra Konveksi di Kecamatan Tingkir Kota Salatiga). Jurnal Ekonomi dan Bisnis, 18(2), 107-126. 